\title{
STRATEGI PENGEMBANGAN DESA MANTAR \\ SEBAGAI KAWASAN DESA WISATA DI KABUPATEN SUMBAWA BARAT
}

\author{
Zaenafi Ariani ${ }^{1)}$, Muhammad Nursan ${ }^{2)}$ \\ Universitas Cordova-Indonesia ${ }^{1)}$ \\ efisholiha@yahoo.co.id \\ Universitas Cordova-Indonesia ${ }^{2)}$ \\ mnursan@yahoo.co.id
}

\begin{abstract}
Mantar Village is a village that is designated as a tourist area by the West Sumbawa Regency Government. Although already established as a tourist village, Mantar Village management as a tourist village is still not maximized. Therefore, the purpose of this study is to determine the main types of tourism and support and determine the strategy of tourism development in Mantar Village. The method used in this research is descriptive research method. Data were collected using survey technique to 40 respondents chosen by purposive sampling. AHP analysis was used to determine the main types of tourism and supporters, and to determine the development strategy Mantar Village tourism was used SWOT analysis.

The results of the study using AHP analysis indicate that the main tourism in Mantar Village based on the criteria of stakeholder support, facilities and infrastructures, and the main tourist attraction in Mantar Village is Nature Tourism (0.3012) and Paragliding Sports Tour (0.2860) and historical and cultural tourism (0.2134) and agricultural tourism (0.1994) are support tours. Mantar Village development strategy as a tourist village in West Sumbawa Regency based on SWOT analysis is a S-O (Strenght-opportunity) strategy that is a strategy that utilizes the power it possesses to seize the opportunity or aggressive strategy. Priority of strategy that need to be done is to arrange Mantar Village tour package and increase cooperation with private party, increase promotion of tourist village, quantity and quality of tourism management HR, supporting facilities and infrastructure, planning development and management of tourist village, socialization in order to increase community awareness related tourist village
\end{abstract}

Keywords: Development Strategy, AHP, SWOT, Tourism, Mantar Village

\section{PENDAHULUAN}

Pariwisata merupakan salah satu sektor penting untuk dikembangkan oleh suatu daerah atau negara. Dengan adanya pengembangan sektor pariwisata dapat meningkatkan pendapatan daerah dimana objek wisata tersebut berada. Selain itu, pariwisata juga merupakan komoditas yang dibutuhkan oleh setiap individu. Hal ini dikarenakan bahwa aktivitas berwisata bagi seorang individu dapat meningkatkan daya kreatif, menghilangkan kejenuhan kerja, relaksasi, berbelanja, bisnis, mengetahui peninggalan sejarah dan budaya suatu etnik tertentu, kesehatan dan pariwisata spiritualisme. Dengan bertambahnya waktu 
luang seorang individu dan didukung oleh meningkatnya penghasilan maka aktivitas kepariwisataan akan semakin meningkat (Yuwana, 2010).

Kabupaten Sumbawa Barat (KSB) merupakan salah satu daerah di Provinsi Nusa Tenggara Barat (NTB) yang memiliki potensi sumberdaya alam yang melimpah, terutama pada sektor pariwisata. Sektor pariwisata di KSB terdiri dari beragam jenis wisata seperti wisata pantai, danau, air terjun, dan desa yang masih kaya akan sumberdaya alam, budaya dan adat istiadat yang akan dijadikan sebagai desa wisata yaitu Desa Mantar. Secara geografis Desa Mantar merupakan salah satu desa di Indonesia yang memiliki karakteristik tersendiri yaitu berada pada ketinggian 586 meter di atas permukaan laut dengan luas sekitar $30.18 \mathrm{~km}^{2}$ (BPS Sumbawa Barat, 2014).

Desa ini memiliki sumberdaya alam dan pemandangan yang sangat indah, sangat kaya akan seni dan budaya asli masyarakat sumbawa (suku samawa) mulai dari kebiasaan masyarakat setempat dalam bertani, berburu, beternak masih sederhana dan traditional. Selain itu, di desa ini kebiasaan dan budaya masyarakat serta peninggalan sejarah juga masih tetap dijaga seperti Barapan Kebo (balapan kerbau),
Barapan Ayam (balapan ayam), Maen Jaran (kuda pacuan), Kesenian Dempa (Adu Kaki), kesenian sakecoh atau (berbalas pantun ala masyarakat sumbawa), acara-acara pernikahan dan peninggalanpeninggalan sejarah seperti guci cina dan pusaka lainnya masih dijaga dan dipelihara oleh masyarakat setempat. Potensi potensi inilah perlu dikelolah dengan baik supaya desa mantar sebagai desa budaya dapat menjadi desa wisata yang dapat meningkatkan perekonomian masyarakat dan daerah.

Permasalahan yang terjadi saat ini adalah potensi-potensi tersebut belum dapat dikelolah (managed) dan dikemas dengan baik oleh pemerintah daerah Kabupaten Sumbawa Barat dan masyarakat setempat karena kurangnya pengetahuan, sumberdaya dan teknologi. Belum adanya konsep desa wisata yang matang menyebabkan desa wisata ini hanya didatangi saja oleh wisatawan tanpa adanya nilai tambah atau pemasukan yang bisa dinikmati oleh masyarakat. Oleh karena itu tujuan penelitian ini yaitu 1) Untuk menentukan jenis wisata utama dan pendukung di Desa Mantar; 2) Untuk mengetahui strategi pengembangan Desa Mantar sebagai kawasan desa wisata di Kabupaten Sumbawa Barat. 


\section{METODE PENELITIAN}

Metode yang digunakan pada penelitian ini adalah metode penelitian deskriptif. Data dikumpulkan menggunakan teknik survey terhadap 40 responden yang dipilih secara purposive sampling. Analisis AHP digunakan untuk menentukan jenis wisata utama dan pendukung, sedangkan untuk menentukan strategi pengembangan wisata Desa Mantar digunakan analisis SWOT.

\section{HASIL DAN PEMBAHASAN}

\section{Penentuan Jenis Wisata Utama dan Pendukung Menggunakan AHP}

Analytic hierarchy process (AHP) digunakan untuk menentukan dan memilih prioritas jenis wisata yang terdapat di Desa Mantar Kabupaten Sumbawa Barat berdasarkan hirarki masalah yang disusun dari hasil studi pustaka dan pendapat pakar atau ahli. Kriteria yang digunakan dalam AHP penentuan prioritas jenis wisata utama dan pendukung meliputi Dukungan Stakeholder (DD), Sarana dan Prasaran (SPS) dan Kriteria Daya Tarik (DT).

- Kriteria Dukungan Stakeholder (DD)
Kriteria ini untuk melihat sejauh mana dukungan dari masyarakat dan pemerintah daerah terhadap pengelolaan jenis-jenis wisata yang terdapat di Desa Mantar sehingga dapat meningkatkan pendapatan masyarakat maupun daerah.

- Sarana dan Prasaran (SPS)

Kriteria ini untuk mengetahui ketersediaan sarana dan prasarana yang terdapat di Desa Mantar. Aspek ini sangat penting dalam mendukung Desa Mantar sebagai kawasan Desa Wisata di Kabupaten Sumbawa Barat.

- Daya Tarik (DT)

Kriteria ini untuk melihat daya tarik dari jenis wisata yang terdapat di Desa Mantar sehingga dapat meningkatkan kunjungan wisatawan nusantara maupun mancanegara.

Penentuan jenis wisata utama dan pendukung di Desa Mantar menggunakan AHP disusun berdasarkan kriteria Dukungan Stakeholder (DD), Sarana dan Prasaran (SPS) dan Kriteria Daya Tarik (DT) dengan alternative jenis wisata yaitu Wisata Sejarah dan Budata (WSB), Wisata Alam (WA), Wisata Paralayang (WO), dan Wisata Pertanian (WP).

Berdasarkan hasil analisis AHP dengan para pakar dalam menentukan jenis wisata utama dan pendukung diperoleh 
bahwa kriteria Daya Tarik (DT) memiliki nilai tertinggi atau prioritas utama dengan nilai sebesar 0.3714. kemudian kriteria Dukungan Stakeholder memiliki nilai sebesar 0.3238 dan Sarana dan Prasarana memiliki nilai sebesar 0.3048 .

Berdasarkan hasil analisis AHP berdasarkan kriteria dengan jenis wisata diperoleh bahwa pada kriteria Daya Tarik (DT) wisata yang menjadi prioritas utama adalah Wisata Alam (0.3050), dan Wisata olahraga Paralayang (0.2695), sedangkan untuk wisata pendukung adalah wisata sejarah dan Budaya (0.2199) dan Wisata Pertanian (0.2057). untuk kriteria Dukungan Stakeholder (DD) yang menjadi prioritas utama dalah wisata olahraga paralayang (0.3121), dan Wisata Alam (0.2979), sedangkan Wisata Sejarah dan Budaya (0.1986), dan Wisata Pertanian (0.1915) menjadi wisata pendukung. Kemudian berdasarkan kriteria sarana dan prasarana yang menjadi wisata utama adalah wisata Alam (0.3000) dan Wisata Olahraga Paralayang (0.2786), sedangkan wisata sejarah dan Budaya (0.2214) dan wisata pertanian (0.2000) dapat menjadi wisata pendukung.

Berdasarkan hasil analisis AHP secara keseluruhan dengan tujuan penentuan prioritas wisata utama dan pendukung dari berbagai kriteria dan jenis wisata yang terdapat di Desa Mantar maka diperoleh bahwa Wisata Alam (0.3012) dan Wisata Olahraga Paralayang (0.2860) menjadi jenis wisata utama sedangkan untuk wisata pendukungnya adalah wisata sejarah dan Budaya (0.2134) serta wisata pertanian (0.1994). Adapun secara rinci mengenai prioritas jenis wisata di Desa Mantar dapat dilihat pada Gambar.

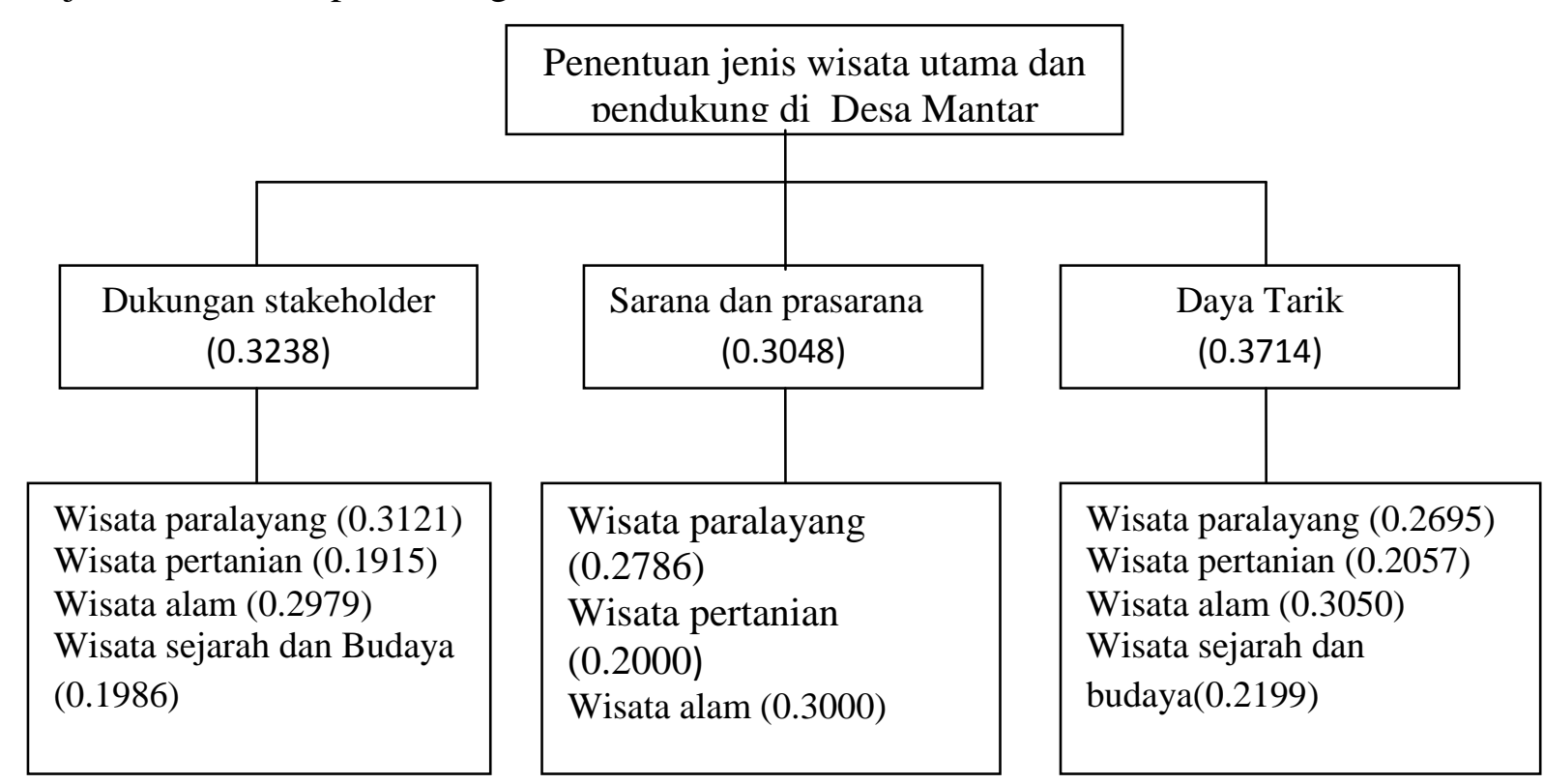


Gambar 2. Struktur hierarki wisata Desa Mantar

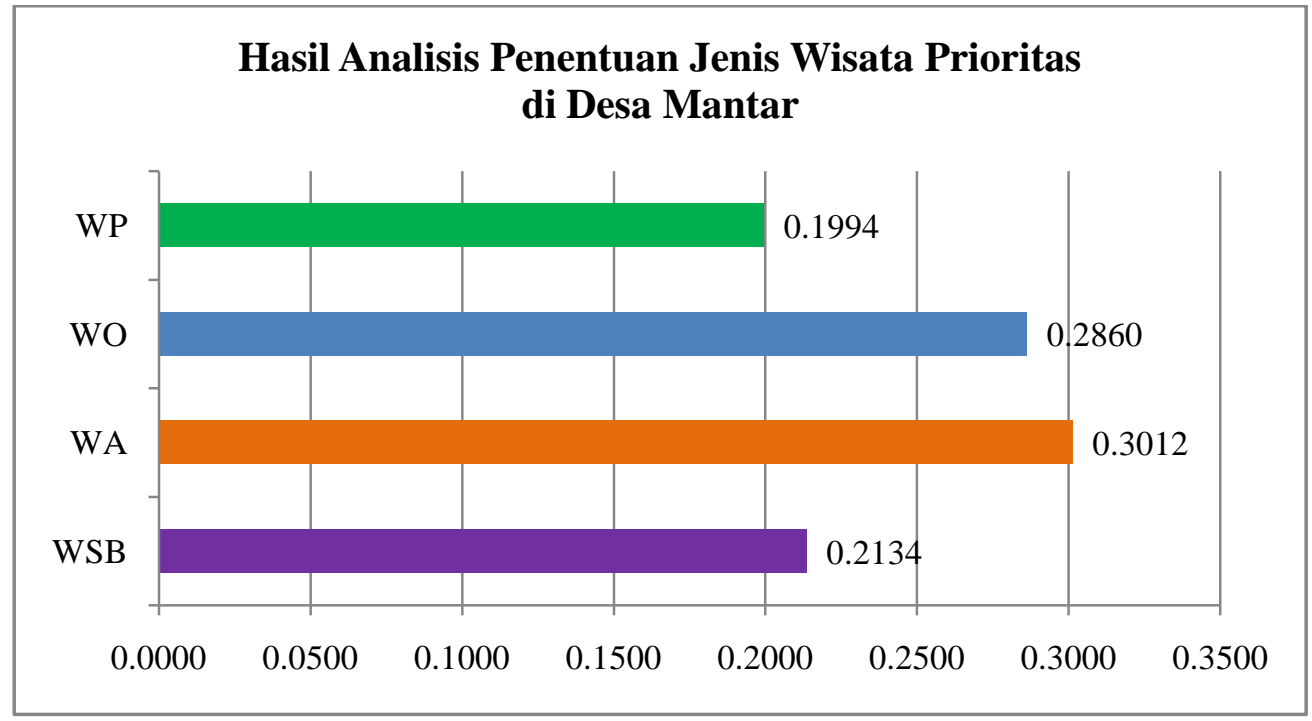

Gambar 3. Hasil Analisis Penentuan Jenis Wisata Prioritas di Desa Mantar

\section{Analisis SWOT Pengembangan Desa} Mantar sebagai Kawasan Desa Wisata

Pariwisata merupakan salah satu sektor penting yang perlu dikembangkan karena merupakan salah satu sektor penggerak ekonomi di Kabupaten Sumbawa Barat. Oleh karena itu dalam rangka meningkatkan peran sektor pariwisata sangat diperlukan kerjasama antara berbagai pihak. Dalam pengelolaan kawasan pariwisata di Desa Mantar sebagai kawasan desa wisata di Kabupaten Sumbawa Barat. Penentuan strategi pengembangan Desa Mantar sebagai kawasan desa wisata di Kabupaten Sumbawa Barat dilakukan dengan menggunakan analisis SWOT (Strength,
Weakness, Opportunity, Threat). Kondisi dari dalam desa yang memiliki sifat positif (kekuatan) dan sifat negatif (kelemahan) dilihat sebagai faktor internal, sedangkan faktor-faktor yang berasal dari luar desa yang berupa ancaman dan peluang disebut sebagai faktor eksternal. Dari hasil penelitian diperoleh faktor internal dan faktor eksternal sebagai berikut :

1. Faktor internal

Faktor internal desa mantar sebagai kawasan desa wisata di Kabupaten Sumbawa Barat terdiri atas faktor kekuatan (strength) dan faktor kelemahan (weakness).

a. Kekuatan 
- Memiliki daya tarik wisata yang khas

- Memiliki budaya dan sejarah yang unik

- Adanya berbagai jenis wisata

- Peraturan perundangan tentang pariwisata

b. Kelemahan

- kurangnya promosi dan pemasaran desa wisata

- kurangnya SDM pengelolah desa wisata

- Sarana dan prasarana penunjang desa wisata yang kurang

2. Faktor eksternal

Faktor eksternal desa mantar sebagai kawasan desa wisata di Kabupaten Sumbawa Barat terdiri atas faktor peluang (opportunity) dan faktor ancaman (threat).

a. Peluang
- Pasar wisatawan yang terbuka

- sudah ada akses menuju desa wisata

- dukungan dari pemerintah daerah dan pihak swasta

- peningkatan jumlah wisatawan

b. Ancaman

- Masuknya budaya asing terhadap budaya masyarakat

- Adanya citra negatif dalam kegiatan wisata

Dari hasil pembobotan faktor internal dan eksternal maka kemudian dianalisis untuk mendapatkan hasil analisis faktor internal dan eksternal yang dapat mempengaruhi pengembangan pariwisata di Desa Mantar di Kabupaten Sumbawa Barat yaitu melalui perkalian antara rating kali bobot. Secara jelas hasil analisis faktor internal dan eksternal disajikan pada tabel di bawah ini.

\section{Analisis Faktor Internal}

Tabel 5. Analisis Faktor Internal

\begin{tabular}{lcccc}
\hline \multicolumn{1}{c}{ Kekuatan } & Bobot & Rating & Bobot x Rating & Kode \\
\hline Memiliki daya tarik wisata yang khas & 0.10 & 4 & 0.39 & S1 \\
Memiliki budaya dan sejarah yang unik & 0.08 & 3 & 0.23 & S2 \\
Adanya berbagai jenis wisata & 0.08 & 3 & 0.24 & S3 \\
$\begin{array}{l}\text { Peraturan perundangan tentang pariwisata } \\
\text { Kelemahan }\end{array}$ & 0.08 & 3 & 0.24 & S4 \\
Kurangnya promosi dan pemasaran Desa & & & 1.09 & \\
Kurata & 0.06 & 2 & & W1 \\
$\begin{array}{l}\text { Kisangnya SDM Pengelolah Desa Wisata } \\
\text { Sarana dan prasarana penunjang Desa }\end{array}$ & 0.07 & 3 & 0.11 & W2 \\
\end{tabular}


Wisata yang kurang dimanfaatkan

Sub total

0.43

Total

0.66

2. Analisis Faktor Eksternal

Tabel 6. Analisis Faktor Eksternal

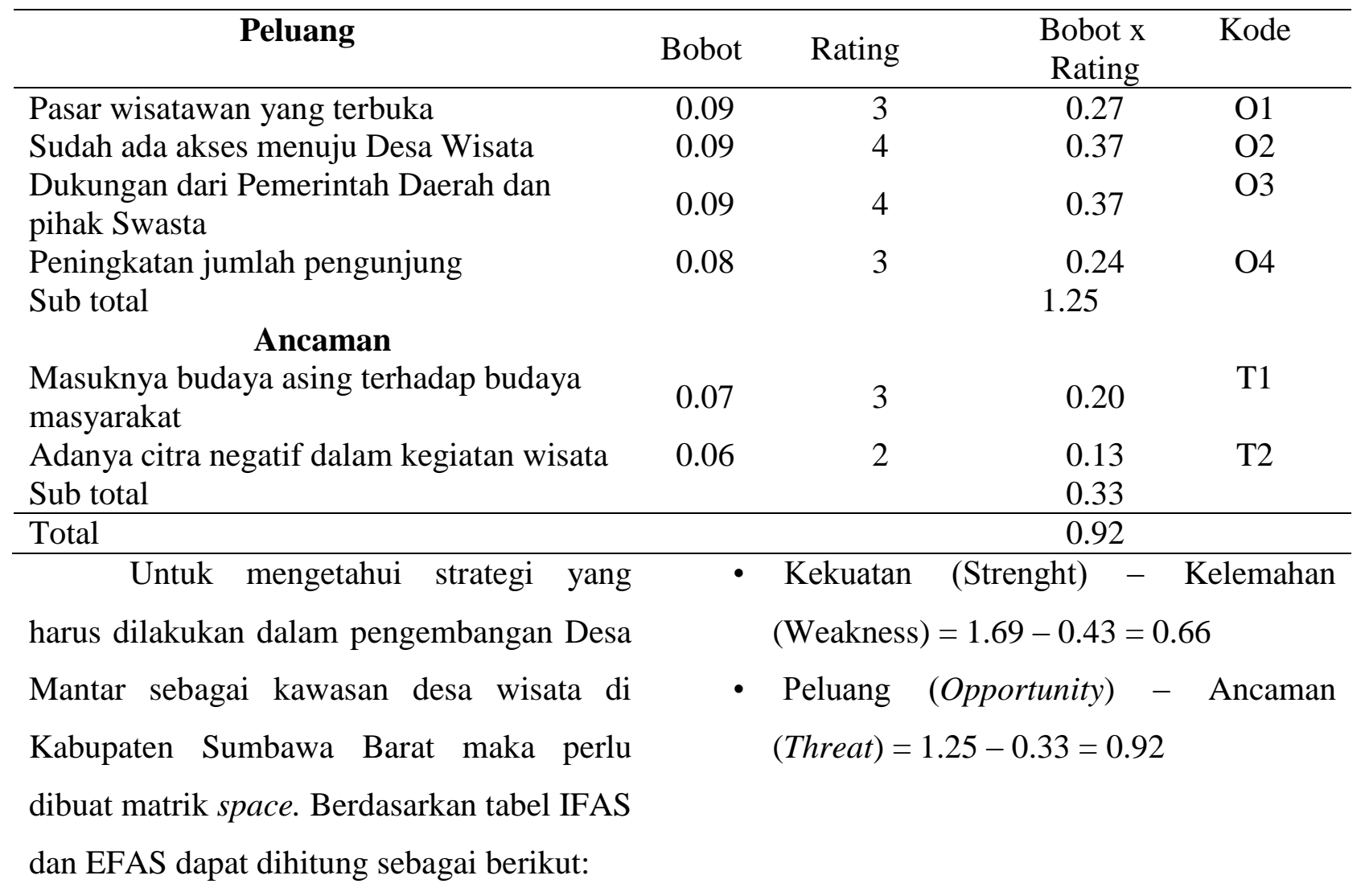

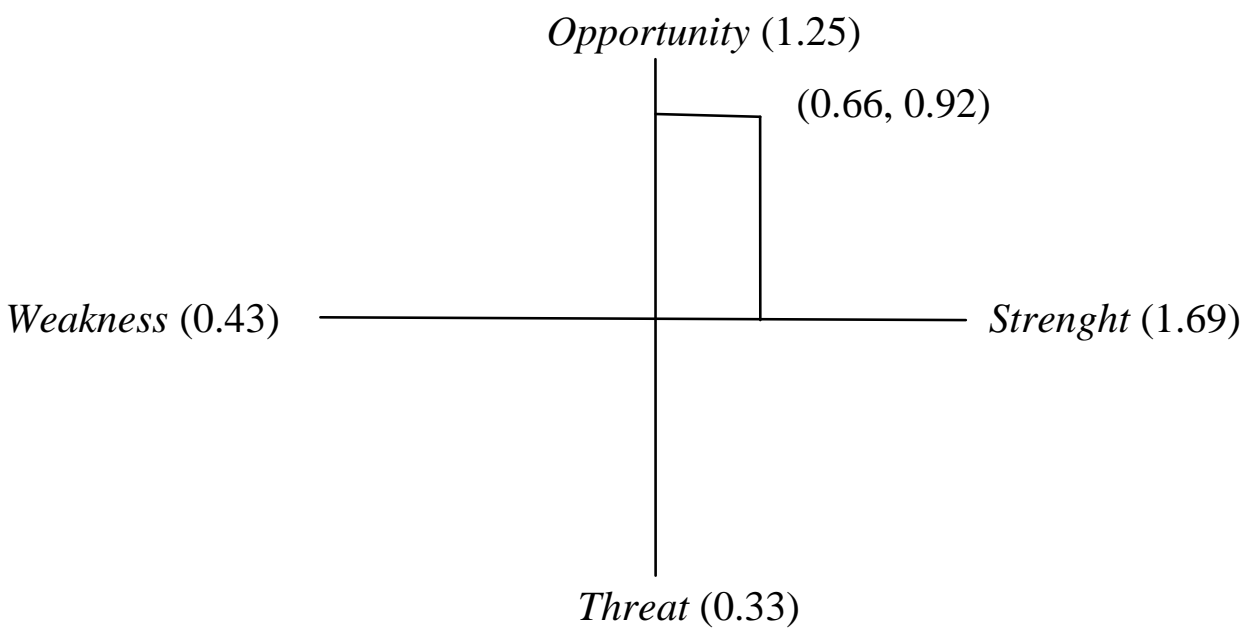

Gambar 4. Matrik Space 


\section{Berdasarkan hasil analisis SWOT}

menunjukan bahwa dalam rangka

mendukung Desa Mantar sebagai kawasan desa wisata di Kabupaten Sumbawa Barat maka strategi pengembangan yang perlu dilakukan adalah strategi S-O (Strenghtopportunity) yaitu strategi yang memanfaatkan kekuatan yang dimiliki untuk meraih peluang atau strategi agresif. Desa Mantar memiliki kekuatan atau kelebihan sebagai kawasan desa wisata yaitu memiliki daya tarik wisata yang khas dengan berbagai kesenian masyarakat desa, memilki sejarah dan budaya, adanya berbagai jenis wisata seperti wisata alam, olahraga, pertanian, dan wisata sejarah serta budaya. Dengan adanya kekuatan yang dimiliki maka peluangpeluang pariwisata harus dapat diraih dimana pasar pariwisata masih terbuka luas dan adanya dukungan dari pemerintah daerah dan swasta.

\section{Strategi Pengembangan Desa Mantar}

Strategi menurut Ramli (2010) adalah suatu seni menggunakan kemampuan dan sumberdaya yang dimiliki suatu organisasi untuk mencapai sasarannya melalui hubungan yang efektif dengan lingkungan dalam kondisi saling menguntungkan. Tipe strategi meliputi (1) strategi organisasi, (2) strategi program, (3) strategi pendukung sumberdaya dan (4) strategi kelembagaan. Strategi pengembangan pariwisata menitikberatkan pada strategi pendukung sumberdaya dan strategi kelembagaan. Berdasarkan analisis SWOT maka Alternatif strategi yang dapat dirumuskan dalam mengembangkan Desa Mantar sebagai kawasan desa wisata di Kabupaten Sumbawa Barat yaitu:

Tabel 7. Strategi Pengembangan Desa Mantar sebagai Kawasan Desa Wisata

\begin{tabular}{|c|c|c|c|c|}
\hline Strategi & Kode Pembobotan & Nilai & Prioritas & Ket \\
\hline $\begin{array}{lccc}\text { Menyusun } & \text { paket } & \text { wisata Desa } \\
\text { Mantar } & \text { dan } & \text { Meningkatkan }\end{array}$ & $\mathrm{S} 1+\mathrm{S} 2+\mathrm{S} 3+\mathrm{S} 4+\mathrm{O} 1+\mathrm{O} 2+\mathrm{O} 3$ & 2.10 & 1 & SO \\
\hline $\begin{array}{l}\text { Mantar dan Meningkatkan } \\
\text { kerjasama dengan pihak swasta }\end{array}$ & & & & \\
\hline $\begin{array}{l}\text { Pemerintah Daerah merencanakan } \\
\text { pengembangan dan pengelolaan } \\
\text { desa wisata }\end{array}$ & $\mathrm{S} 1+\mathrm{S} 2+\mathrm{S} 3+\mathrm{S} 4+\mathrm{T} 1+\mathrm{T} 2$ & 1.42 & 3 & ST \\
\hline $\begin{array}{l}\text { Meningkatkan promosi desa } \\
\text { wisata, kuantitas dan kualitas } \\
\text { SDM pengelolah wisata, sarana } \\
\text { dan prasarana penunjang }\end{array}$ & $\begin{array}{l}\mathrm{W} 1+\mathrm{W} 2+\mathrm{W} 3+ \\
\mathrm{O} 1+\mathrm{O} 2+\mathrm{O} 3+\mathrm{O} 4\end{array}$ & 1.68 & 2 & WO \\
\hline $\begin{array}{l}\text { Melakukan Sosialisasi dalam } \\
\text { rangka meningkatkan kesadaran } \\
\text { masyarakat terkait desa wisata }\end{array}$ & $\mathrm{W} 1+\mathrm{W} 2+\mathrm{T} 1+\mathrm{T} 2$ & 0.66 & 4 & WT \\
\hline
\end{tabular}


1. Menyusun paket wisata Desa Mantar dan Meningkatkan kerjasama dengan pihak swasta

Strategi ini dipilih untuk memanfaatkan kekuatan yang ada untuk mendapatkan peluang. Daya tarik wisata berupa keindahan alam, wisata olahraga, sejarah dan budaya yang dimiliki Desa Mantar sangat berpeluang untuk dikembangkan dalam pengembangan Desa Wisata begitu juga dengan kehidupan masyarakat desa yang masih tradisional, dan kesenian daerah, dapat dijadikan sebagai daya tarik lain wisata untuk dikemas dalam paket wisata Desa Mantar. Paket wisata ini sangat membutuhkan kerjasama dengan pihak swasta seperti lembaga pembiayaan, pihak agen perjalanan wisata.

2. Meningkatkan promosi desa wisata, kuantitas dan kualitas SDM pengelolah wisata, sarana dan prasarana penunjang. Strategi ini dipilih untuk mendapatkan peluang dengan meminimalisir kelemahan. Desa Mantar harus sering dipromosikan melalui berbagai media baik di media cetak maupun elektronik oleh Pemerintah Daerah. Promosi juga dapat dilakukan dengan cara mengikuti pameranpameran diberbagai tempat yang bisa menginformasikan keberadaan Desa Wisata
Mantar. Disamping itu, hal yang harus diperhatikan juga adalah keberadaan SDM pengelola wisata baik secara kuantitas dan kualitas serta adanya sarana dan prasarana penunjang Desa Wisata Mantar.

3. Merencanakan pengembangan dan pengelolaan desa wisata

$\begin{array}{rcr}\text { Strategi } & \text { ini dipilih untuk } \\ \text { meminimalkan } & \text { ancaman } & \text { dengan }\end{array}$
memanfaatkan kekuatan. Banyaknya pengunjung baik dari dalam maupun dari luar negeri akan membawa dampak yang baik dan tidak baik terhadap penduduk lokal. Oleh karena itu, untuk menghindari adanya dampak yang tidak baik dari aktivitas pariwsata pemerintah daerah perlu membuat kebijakan pengembangan dan pengelolaan pariwisata Desa Mantar dengan baik.

4. Melakukan Sosialisasi dalam rangka meningkatkan kesadaran masyarakat terkait desa wisata

Strategi ini dipilih untuk meminimalkan kelemahan dan ancaman yang ada. Menurut Rahardjo (2005) mengatakan bahawa kunci sukses pengembangan pariwisata yaitu keterlibatan masyarakat. Dalam rangka meningkatkan kesadaran wisata di bagi masyarakat Desa Mantar maka perlu dilakukannya sosialisasi dan pembinaan terhadap masyarakat agar 
dapat sadar wisata dan menghindari atau mencegah pengaruh negatif dari adanya aktivitas wisata. Hasil analisis SWOT menunjukkan bahwa strategi yang perlu dilakukan dalam pengembangan Desa Mantar sebagai kawasan desa wisata di Kabupaten Sumbawa Barat adalah strategi S-O (Strenght-opportunity) yaitu strategi yang memanfaatkan kekuatan yang dimiliki untuk meraih peluang atau strategi agresif. Sehingga prioritas strategi yang perlu dilakukan yaitu menyusun paket wisata Desa Mantar dan meningkatkan kerjasama dengan pihak swasta, meningkatkan promosi desa wisata, kuantitas dan kualitas sdm pengelolah wisata, sarana dan prasarana penunjang, merencanakan pengembangan dan pengelolaan desa wisata, melakukan sosialisasi dalam rangka meningkatkan kesadaran masyarakat terkait desa wisata.

\section{KESIMPULAN DAN SARAN}

\section{Kesimpulan}

Berdasarkan hasil analisis dan pembahasan yang dicapai pada penelitian maka dapat disimpulkan bahwa:

1. Jenis wisata prioritas di Desa Mantar adalah Wisata Alam (0.3012) dan Wisata Olahraga Paralayang (0.2860) menjadi jenis wisata utama sedangkan untuk wisata pendukungnya adalah wisata sejarah dan Budaya (0.2134) serta wisata pertanian (0.1994).

2. Kondisi internal desa Mantar meliputi kekuatan yaitu adanya daya tarik wisata yang khas dan adanya berbagai jenis wisata, untuk kelemahan masih kurangnya SDM pengelolah desa wisata, Sedangkan kondisi eksternal terdiri atas Peluang yaitu dukungan dari pemerintah daerah dan pihak swasta, dan peningkatan jumlah wisatawan dan Ancaman yang perlu diwaspadai adalah masuknya budaya asing terhadap budaya masyarakat.

3. Strategi pengembangan Desa Mantar sebagai kawasan desa wisata di Kabupaten Sumbawa Barat adalah strategi S-O (Strenght-opportunity) yaitu strategi yang memanfaatkan kekuatan yang dimiliki untuk meraih peluang atau strategi agresif. Sehingga prioritas strategi yang perlu dilakukan yaitu Menyusun paket wisata Desa Mantar dan Meningkatkan kerjasama dengan pihak swasta, Meningkatkan promosi desa wisata, kuantitas dan kualitas SDM pengelolah wisata, sarana dan prasarana penunjang, Merencanakan pengembangan dan pengelolaan desa wisata, Melakukan Sosialisasi dalam rangka meningkatkan 
kesadaran masyarakat terkait desa wisata

\section{Saran}

Berdasarkan hasil yang diperoleh sementara pada penelitian maka dapat disarankan beberapa hal berikuti ini:

1. Untuk meningkatkan pengelolaan desa mantar sebagai desa wisata perlu dukungan dari pemerintah, pihak swasta maupun pergurungan tinggi untuk memberikan pelatihan dan kesadaran kepada masyarakat desa dalam mengelolah desa wisata dengan baik sehingga dapat meningkatkan pendapatan masyarakat.

2. Perlu dukungan dari pemerintah daerah dalam meningkatkan sarana dan prasarana penunjang produk wisata.

3. Sosialisasi terait jenis-jenis wisata utama dan pendukung yang terdapat di Desa Mantar perlu dilakukan oleh pemerintah daerah dan desa sehingga dapat menarik kunjungan wisatawan nusantara dan mancanegara.

\section{DAFTAR PUSTAKA}

Marimin., N. Maghfiroh. 2010. Aplikasi Teknik Pengambilan Keputusan dalam Manajemen Rantai Pasok. IPB Press. Bogor.
Oddershede A, Arias A, Cancino H. 2007. Rural development decision support using the analytic hierarchy process. JMCM. 46(2):1107-1114.

Osuna, E.E and A. Aranda. 2007. Combining SWOT and AHP techniques for strategic planning. ISAHP. 1-8.

Prasiasa, P.O. 2012. Destinasi Pariwisata, Berbasis Masyarakat. Salemba Empat. Jakarta.

Rangkuti. 2009. SWOT Analysis. Gramedia. Jakarta.

Saaty T.L. 2008. Decision making with the analytic hierarchy process. Int. J. Services Sciences. 1(1):83-98.

Yuwana, D.M.S. 2010. Analisis Permintaan Kunjungan Objek Wisata Kawasan Dataran Tinggi Dieng Kabupaten Banjarnegara. Tesis. Universitas Diponegoro. Semarang. 